\title{
Rızâeddin b. Fahreddin'in Yeni Mecelle Mücadelesi
}

\author{
Kibar KARADENIZ*
}

Atıf/Cite as: Karadeniz, Kibar. "Rızâeddin b. Fahreddin'in Yeni Mecelle Mücadelesi". Recep Tayyip Erdoğan Üniversitesi İlahiyat Fakültesi Dergisi 20 (2021), 140-164.

Öz: Rızâeddin b. Fahreddin, Rusya Müslümanlarının önde gelen âlimlerindendir. Rızâeddin Mahkeme-i Şer'iyye'ye kadı olarak atandığında, mahkemenin kazâ açısından yaşadığı problemleri gündeme getirip, çözüm olarak da bir mecellenin hazırlanmasının gerekliliğini ilk olarak dile getirmiştir. Bu düşünce doğrultusunda yaptığ1 çalışmalarla yeni mecellenin fikrî altyapısını oluşturmuştur. 1910 yılında Musa Carullah'a, mecelleye medhâl mahiyetinde ve külli kâideler mesabesinde Kavâid-i Fıkhiyye'yi hazırlatmıştır. Rızâeddin'in çalışmaları, Mahkeme-i Şer'iyye'nin 1917 yılında özerk bir yapıya kavuşmasıyla, Rusya Müslüman âlimlerinin ilk iş olarak ele alıp, Mecelle-i Ahkâm-ı Şer'iyye adıyla resmiyet kazandırdıkları yeni mecellenin projelendirilmesinde kendisini etkin bir şekilde göstermiştir. Ancak bu büyük proje, Rusya'da yaşanan Bolşevik Devrimi ile 1923 yılına kadar sürecek bir sekteye uğramıştır. Rızâeddin b. Fahreddin'in 1923 yılında Mahkeme-i Şer'iyye'ye müftü seçilmesi Mecelle-i Ahkâm-1 Şer'iyye için bir umut olmuştur. Umulduğu gibi olmuş, çok ağır siyasi ve ekonomik sıkıntılara rağmen Mecelle-i Ahkâm-1 Şer'iyye'nin yeni bir metotla kısa zaman içinde hazırlanmasına karar verilmiştir. Bölümler halinde hazırlanması planlanan mecelle için konusunun uzmanı sayılan kişilere görevlendirmeler yapılmıştır. Ancak Abdurrahman Ömerî tarafından hazırlanan aile hukukuna dair 551 maddelik bölümün dışında diğer bölümlerle ilgili herhangi bir çalışmaya bugüne kadar rastlanılamamıştır. Aile hukukuna dair bölümün hazırlanarak önemli bir adım atılmış olmasına rağmen içinde bulunulan şartların zorluğu ve Müslümanların yeterli desteği vermemesi Rizâeddin b. Fahreddin'in onlarca yll diri tuttuğu umudunu yitirmesine sebebiyet vermiştir. Böylece, Rızâeddin'in kadılığı zamanında gündeme getirdiği ve yaklaşık otuz beş yıl boyunca mücadelesini verdiği yeni mecelle düşüncesi akîm kalmıştır.

Anahtar Kelimeler: İslam hukuku, Rusya Müslümanları, Rızâeddin b. Fahreddin, Mecelle, Mahkeme-i Şer'iyye, Kadı.

* Doktora Öğr., Süleyman Demirel Üniversitesi, Isparta, Türkiye, kibarkaradeniz@gmail.com, ORCID: www.orcid.org/0000-0003-4973-6740 


\section{Rizâeddin bin Fakhreddin's The New Majallah Struggle}

Abstract: Rizâeddin bin Fakhreddin is one of the most prominent scholars of Russian Muslims. When Rizâeddin bin Fakhreddin was appointed as a qāọi (judge) of the Mahkama-i Shar'iyyah (the Court of Islamic Law), he prioritised the problems that the Court had been experiencing in terms of qazā (jurisdiction) and he was the first person who emphasised the necessity for preparing a majallah as the solution for those problems. With his academic research, he established the intellectual infrastructure of the new Majallah. In 1910, Musa Jarullah (Bigiev) and he prepared the "Qawâid-i Fiqhiyyah (Rules of Fikh)" which consist of general principles and might be taken as an introductory basis of the Majallah. Upon the Mahkama-i Shar'iyyah's gaining an autonomous structure in 1917, the influence of Rizâeddin's contributions were explicitly noticeable over the new Majallah project that the Russian Muslim firstly have addressed and formalized under the name of Majalla-i Ahkâm-i Shar'iyyah. However, this essential project was stopped until 1923 due to the Bolshevik Revolution that took place in Russia. The election of Rizâeddin bin Fakhreddin as a muftī (jurisconsult) of the Mahkama-i Shar'iyyah in 1923 increased the expectations for the formation of Majalla-i Ahkam-i Shar'iyyah. Although there were quite complex political and economic problems, it was decided to prepare the Majalla-i Ahkâm-i Shar'iyyah with a new method in a short time. The scholars who were deemed to be experts in their subjects, were appointed for the preparation of Majallah which was planned to include several sections. However up until now, the sessions were absent except the one which was prepared by Abdurrahman al-Omari including 551 articles regarding the family law. Despite making important improvements by preparing the family law, Rızâeddin bin Fakhreddin lost his expectations because of existing difficult conditions and the lack of support by the Muslims. As a result, the idea of new Majallah failed, which Rızâeddin had prioritised during his time as the qāḍi and had struggled almost thirty five years.

Keywords: Islamic Law, Russian Muslims, Rızâeddin bin Fakhreddin, Majallah, Mahkama-i Shar'iyyah, qāệ̄

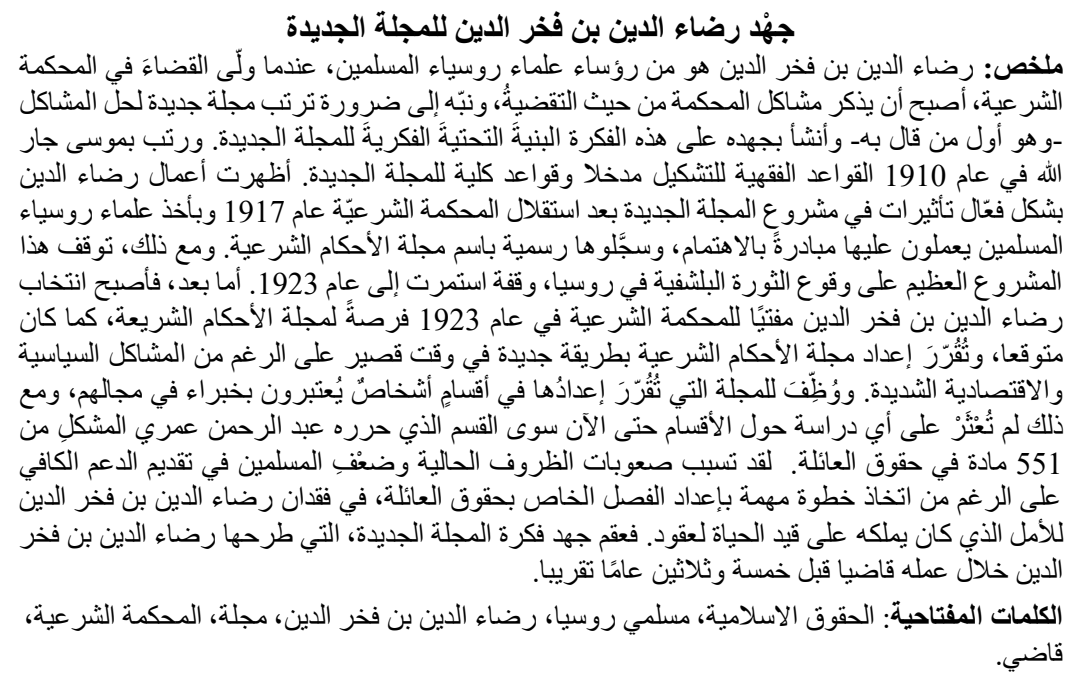


142

Rızâeddin b. Fahreddin'in Yeni Mecelle Mücadelesi

RTEÜIFD

\section{GíRiş}

Bağımsızlıklarını kaybedip gayri müslim Rusya'nın egemenliği altında yaşamak zorunda kalan ve Rusya Müslümanları olarak adlandırılan milletler, tarih içinde din ve kimliklerini korumak adına çok önemli mücadeleler vermişlerdir. Hemen her büyük mücadelede olduğu gibi Rusya Müslümanlarının mücadelelerinin de sembol şahsiyetleri vardır. Bu şahsiyetlerden biri de Rızâeddin b. Fahreddin'dir. Rızâeddin birçok alanda adından söz ettirmiş bir İslam âlimidir. Bu çalışmamızda onun yeni bir mecelle hazırlanması için verdiği mücadele sürecini ele almaya çalışacağız. Ancak öncelikle Rıâeddin b. Fahreddin'in biyografisine ve mecelle ile neyin kastedildiğine kisaca yer vermek istiyoruz.

\section{R1zâeddin b. Fahreddin}

Rusya Müslüman âlimlerinin önde gelen şahsiyetlerinden olan Rızâeddin b. Fahreddin, 31 Aralık 1858' de bugünkü Tataristan sınırları içinde yer alan Bügülme' de dünyaya gelmiştir. İlk eğitiminden sonra başladığı medrese hayatı, ilmi açıdan kendisine çok büyük katkı sağlamış ve birçok klasik eseri burada istinsah etmiştir. Rızâeddin b. Fahreddin'in düşünce dünyasında ilk önce Gaspıralı İsmail'in sonra da Rusya Müslümanlarının ıslahatçı fikirleriyle bilinen âlimi Şehâbeddin Mercânî'nin etkisi görülmüştür. Ancak Rızâeddin'in fikri yapısını en çok etkileyen kişi, 1888 yılında Petersburg'da görüştüğü Cemâleddîn Efgânî'dir. ${ }^{1}$

Rızâeddin b. Fahreddin'in görev safahatı, öğrenim gördüğü Tüben Şelçeli (Aşağ1 Çırşılı) Medresesi'nde 1887'de müderris olarak başlamıştır. Rızâeddin'in 23 Ocak 1891'de, Rusya Müslümanlarının² tek dinî ve aynı zamanda çatı kuruluşu olan

1 Abdullah Battal Taymas, Kazanlı Türk Meşhurlarından I; Rızâeddin Fahreddinoğlu (İstanbul: Birlik Basın ve Yayınevi, 1958), 9-10; İsmail Türkoğlu, Rusya Türkleri Arasındaki Yenileşme Hareketinin Öncülerinden Rızâeddin Fahreddin ( İstanbul: Ötüken Neşriyat, 2000), 21-30; Goulnar Baltanova, "Rızâeddin Fahreddin", Türkiye Diyanet Vakfı İslam Ansiklopedisi (Ankara: TDV Yayınları, 2008), 35/70.

2 Rusya Müslümanları: İdil-Ural Bölgesinde kurulmuş ve ilk Müslüman Türk Devleti olarak kabul edilen İdil Bulgar Devleti'nin, XIII. yüzyılın ortalarında Altın Orda Hanlığı'na bağlanması, 1437 yılında da Altın Orda Devleti'nin Kazan Hanlığı tarafından ortadan kaldırılmasıyla IX. yüzyıldan beri bağımsız devlet geleneklerini sürdüren bölge Müslümanları, 1552 yılında Kazan Hanlığı'nın Ruslar tarafından işgal edilmesiyle, Orta İdil bölgesindeki bağımsız Müslüman devlet geleneği sona ermiştir. Bundan sonra Sibirya'dan Kafkaslar'a kadar Rusya'nın çeşitli bölgelerine dağılan Müslümanlar için Rus hâkimiyeti altında zorluklarla dolu bir yaşam sürmeye çalışan Müslümanlar, Rusya Müslümanları olarak adlandırılmıştır. [Bk. Nesimi Yazıcı, İlk Türk-İslam Devletleri Tarihi (Ankara: TDV Yayınları, 2002), 120; Abdullah Battal Taymas, Kazan Türkleri (Ankara: Türk Kültürü Araştırma Enstitüsü, 1966), 18-23, 62-72; Mehmet Saray, "Altın Orda Hanlığ1", Türkiye Diyanet Vakfi İslam Ansiklopedisi (Ankara: TDV Yayınları, 1989), 2/538-540; İsmail Türkoğlu, "Kazan Hanlığı” Türkiye Diyanet Vakfi İslam Ansiklopedisi (Ankara: TDV Yayınları, 2002), 25/136-138; Fatih Ünal, “Geçmişten Günümüze As-Tarhan (Astrahan/Hac1 Tarhan)”, Atatürk Üniversitesi Türkiyat Araştırmaları Enstitüsü Dergisi Sayı 38 (2008), 250.] 
Mahkeme-i Şer'iyye'ye ${ }^{3}$ kadı olarak atanması hem kendisi hem de mahkeme açısından dönüm noktasıdır. 1906 yılına kadar devam ettiği kadılık görevi yalnız mahkemenin işlerinin iyi ve düzenli yürütülmesi bakımından değil, Mahkeme-i Şer'iyye' ye bağlı Müslümanların fikir hayatının gelişmesi ve yükselmesi yönünden de çok faydalı olmuştur. Bu görevde iken İslam klasiklerini okuma ve İslam dünyasındaki fikir hareketlerini takip etme fırsatını bulan Rızâeddin, Âsâr adlı biyografik eserini, Mahkeme-i Şer'iyye'nin arşiv ve kütüphanesinden yararlanarak hazırlamıştır. Islâh-1 Lisân-1 Türkî, Islâh-1 Mekâtib ve Neşr-i Maârif Beyne'l-Müslimîn adlı cemiyetlerin çalışmalarına katılarak ıslahatçı duruşunu ortaya koymuştur. Bu arada Gaspıralı İsmail ile münasebetini geliştirerek onun fikirlerinin bölgede yayılması ve hayata geçirilmesi için çalışmıştır. ${ }^{4}$

Rızâeddin b. Fahreddin, 1906'da kadılık görevinden istifa ederek gazete faaliyetlerinde bulunmak üzere Orenburg şehrine taşınmıştır. Burada bir taraftan Vakit gazetesinde yazı yazmaya diğer taraftan da, Şûrâ dergisinde editörlük yapmaya başlamıştır. Rızâeddin aynı zamanda Orenburg' daki Hüseyniye Medresesi'nde hadis ve siyer dersleri vererek eğitim faaliyetleri içerisinde kalmaya devam etmiştir. Rızâeddin, Ekim 1917'deki Bolşevik İhtilâli'ni önceleri ümit ve sevinçle karşılayanlar arasında yer almış ancak hayal kırıklığına uğraması uzun sürmemiştir. Çünkü İhtilal sonrasında Rızâeddin'in gazete ve dergisi kapatılmış, o da Mahkeme-i Şer'iyye'ye kadı olarak geri dönmek zorunda kalmıştır. Mahkeme-i Şer'iyye Müftüsü Âlimcan Bârûdî'nin 1921'de vefat etmesiyle boşalan müftülük görevini yaklaşık iki yıl vekâleten yürütmüştür. 1923'te Ufa'da toplanan I. İslam Nedvesi (Kongresi)'nde Mahkeme-i Şer'iyye'ye büyük bir teveccühle müftü seçilmiştir. Rızâeddin, Ağustos 1924 'den itibaren Mahkeme-i Şer'iyye'nin yayın organı olarak İslam Mecellesi adlı dergiyi çıkartarak önemli bir eksikliği gidermiştir. 1925'te Leningrad'da düzenlenen Sovyet Sosyalist Cumhuriyetleri Birliği İlimler Akademisi'nin 200. kuruluş y1l dönümü törenlerine şarkiyat uzmanı olarak çağrılmış, burada birçok görüşme yapma fırsatı

3 Mahkeme-i Şer'iyye: Çarlık Rusya'sında II. Katerina'nın, bir taraftan siyasi emellerini gerçekleştirmek diğer taraftan da Müslümanları elde tutmak maksadıyla 1788 yılında Ufa'da "Orenburgskoe Magometanskoe Duhovnoye Sobraniye (Orenburg İdare-i Ruhaniye-i Muhammediyesi)" adıyla kurdurduğu, bir müftü -ki aynı zamanda mahkeme başkanı- ve üç kadıdan müteşekkil dinî ve resmi kurumdur. Mahkeme-i Şer'iyye başlangıçta mahallelerde görev yapmak isteyen imam ve müezzin adaylarını imtihan ederek atanmalarına dair belge veren bir kurumken zamanla aile hukukuna dair nizâların çözüldüğü ve zamanla da yerelde çözüme kavuşturulamayan davaların görüldüğü bir temyiz mahkemesi hüviyetine dönüşmüştür. Mahkeme-i Şer'iyye, Rus devlet hiyerarşisi bakımından vilayet mahkemeleri statüsünde kabul edilmiştir. Mahkeme-i Şer'iyye, yapısındaki bir takım değişikliklerle birlikte, günümüzde Rusya Müslümanlarının Merkezî Din̂̂ Nezâreti adıyla varlığını devam ettirmektedir. [Rusya Müslümanlarının Merkezi Dini Nezareti Türkiye Temsilciliği, http://rusmusdin.org/dini-nezaret (Erişim 17 Mayıs 2016)].

4 Taymas, Rıâeddin Fahreddinoğlu, 12; Türkoğlu, Rıâeddin Fahreddin, 21-30; Baltanova, "Rızâeddin Fahreddin" 35/70; Ahmet Kanlıdere, Reform Within Islam (İstanbul: Eren Yayınc1lık, 1997), 50-52. 
\begin{tabular}{l|l}
144 \\
RTEÜIFD
\end{tabular} \mid Rizâeddin b. Fahreddin' in Yeni Mecelle Mücadelesi

bulmuştur. 1926 yılında Mekke'de düzenlenen İslam Kongresi'ne SSCB delegelerinin başkanı sıfatıyla katılmıştır. 12 Nisan 1936'da vefat eden Rızâeddin, Ufa'daki Tatar mezarlığına defnedilmiştir. ${ }^{5}$

Rızâeddin b. Fahreddin, Rusya Müslümanlarının Nâsırî ve Mercânî'den sonraki ceditçi şahsiyeti kabul edilmektedir. Rızâeddin b. Fahreddin, yukarıda belirtilen Gaspıralı İsmail, Mercânî, ve Cemâleddîn-i Efgânî'nin yanı sıra Osmanlı müelliflerinden Cevdet Paşa, Nâmık Kemal, Ziyâ Paşa ve Ahmed Midhat Efendi'ye, Arap islahatçılardan Muhammed Abduh ve Kâsım Emîn'e, Hristiyan müelliflerden Corcî Zeydân ve Ferah Antûn'a da özel ilgi göstermiştir. Bu fikir adamları Rızâeddin'in düşünce dünyasında önemli etkiler meydana getirmişlerdir. Rızâeddin, Muhyiddin İbn Arabî ve Nakşî şeyhi Zeynullah Resûlî’ye duyduğu derin saygiya rağmen tasavvufa mesafeli durmuştur. Ceditçi kişiliği ön planda olmasına rağmen, Rızâeddin'in eleştirilerinde daima 1lımlı bir uslûp benimsemesi ona kadîmci âlimler tarafından da saygı ve güven duyulmasını sağlamıştır. Bu durum Rızâeddin'in, Bârûdî'den sonra müftülük makamına gelen ikinci ceditçi olmasında etkin olmuştur. Rızaeddîn siyasî meselelere de ilgi göstermiş, gazete ve dergilerde yayımlanan yazılarında Rusya Müslümanlarının siyasî hareketine yön vermiştir. Bolşevik İhtilali sonrası da fikrî tutumunu muhafaza etmiş ve yeni rejime mesafeli durmuştur. Rızâeddin b. Fahreddin'in ortaya koyduğu fikrî miras, Sovyet rejiminin yaklaşık yetmiş yıl süren baskı ve yasaklarının ardından günümüz Rusya Müslümanları tarafından yeniden keşfedilmiş ve hak ettiği itibarı görmeye başlamıştır. ${ }^{6}$

Rızâeddin b. Fahreddin, uzun yıllar gazete ve dergi çıkartarak Müslümanların içinde bulunduğu durumu en iyi tahlil edenlerden birisi olmuştur. Yurtdışı seyahatlerinden ziyade Rusya içerisinde çokça seyahat ederek ülke Müslümanlarının durumlarını yerinde görmüştür. Ceditçi olarak bilinmesine rağmen, kadîm ile cedit arasında duran, her iki akımın olumlu yanlarını alarak bir sentez yapmaya çalışan 1lımlı bir düşünceyi benimsediğini söylemek mümkündür.

\section{Mecelle}

Mecelle denilince akla Mecelle-i Ahkâm-ı Adliye gelmektedir. Ahmed Cevdet Paşa başkanlığında 1868-1876 yılları arasında, 16 bölüm ve 1851 maddeden ibaret olarak hazırlanan Mecelle-i Ahkâm-1 Adliye, "Mecelle" adıyla meşhur olmuştur. Batı'daki kanunlaştırma hareketlerinin bir sonucu olmasına rağmen tamamen İslam hukukunun içtihatları doğrultusunda hazırlanan Mecelle, kısmi bir medeni kanun olmasına rağmen kanun olarak adlandırılmamıştır. Osmanlı Devleti'nde hazırlanan

5 Taymas, Rızâeddin Fahreddinoğlu, 18-19; Türkoğlu, Rızâeddin Fahreddin, 21-30; Baltanova, "Rızâeddin Fahreddin" 35/70; Kanlıdere, Reform Within Islam, 50-52.

6 Türkoğlu, Rızâeddin Fahreddin, 21-30; Baltanova, "Rızâeddin Fahreddin", 35/70; Kanlıdere, Reform Within Islam, 50-52. 
Mecelle'den yaklaşık 40 yıl sonra Rusya Müslümanlarının bir Mecelle hazırlama girişimi olmuştur.

Osmanlı Devleti'nde ve Rusya Müslümanlarında kanun yerine mecelle adının tercih edilmesi tesadüfi değildir. Zira kavramsal olarak mecelle ile kanun arasında farklar bulunmaktadır. Modern Türk idare hukukunun kurucusu kabul edilen Sıddık Sami Onar, mecellenin kanun veya hukuk anlamına gelmeyen, bazı meseleleri, fikirleri, konuları toplayan küçük hacimli bir kitap olduğunu belirterek mahiyetini şu şekilde açıllamaktadır: “... Esasen mer'î olan ve fakat muhtelif büyük kitapların içinde dağınık bulunan hükümlerden ihtiyaca en uygun ve en çok rastlanan hâdiselere tatbik edilebilecek olanlarını, kolay anlaşılır, açık bir tarzda yazarak tatbikatçıların eline vermek üzere mütehassıs bir ilim heyeti tarafından hazırlanmış bir ilmî eser mahiyetindedir."7 Bu nedenle mecelle, compilation (derleme/tedvîn) kitabı anlamına gelmektedir. ${ }^{8}$ Mecellelerin Onar'ın ifade ettiği kadar kolay hazırlanmadığını Mecelle-i Ahkâm-ı Adliye'den bilmekteyiz. Mecelle her ne kadar kanun olarak adlandırılmasa da her bir mesele kanun formuna aktarılmış ve maddelerin normatif nitelikteki kısmından sonra getirilen kısa bir açıklama ile uygulayıcısına önemli kolaylıklar sağlamıştır. Onar'ın yaptığı bu tespitler Mecelle-i Ahkâm-1 Adliye özelinde doğru olsa da, Cumhuriyet döneminin önemli hukukçularından Hıfzı Veldet Velidedeoğlu'nun mecellenin karşılığının kanunlaştırma olduğu görüşünü de dikkate almak zorundayız. Velidedeoğlu, kanunlaştırma kavramının batı dillerinde karşılığının codification olduğunu bu kavramin da Latince codex kelimesinden türetildiğini, codex kelimesinin ise, büyük kanun, kanunlar mecmuası ve mecelle anlamına geldiğini ifade etmiştir. ${ }^{9}$

Mecelle'yi kanunlaştırmadan farklı kılan bir özellik de, teşrî fonksiyonunun bir neticesi olmamasıdır. Ayrıca Mecelle, Onar'ın da ifade ettiği gibi bir heyet marifetiyle hazırlanan ilmî mahiyeti olan bir eserdir. Bu nedenle pek çok okulda ders kitabı olarak da okutulmuştur. ${ }^{10}$

Mecelle'nin, düstûru'l-amel (uygulanacak temel kanun) olmasının yanında onu fıkıh kitaplarından ayıran önemli bir özelliği de ibadet konularına yer verilmemesidir. Mecelle'nin kabulünden önce Osmanlı mahkemelerinde bazı fıkıh kitapları11 kazâ

7 Sıddık Sami Onar, “Osmanlı İmparatorluğunda İslam Hukukunun Bir Kısmının Codification’u Mecelle", İstanbul Üniversitesi Hukuk Fakültesi Mecmuası, 20/1-4, 64.

8 Onar, “Osmanlı İmparatorluğunda İslam Hukukunun Bir Kısmının Codification'u Mecelle”, 58.

9 Velidedeoğlu, Hıfzı Veldet, Kanunlaştırma Hareketleri ve Tanzimat, (İstanbul, Maarif Vekâleti Maarif Matbaası, 1940), 7.

10 Sami Erdem, “Türkçede Mecelle Literatürü”, Türkiye Araştırmaları Literatür Dergisi, 5 (2005), 673-705.

11 Bu kitapların başlıcaları; Molla Hüsrev'in Dürerü'l-Hükkâm'1 ve İbrâhim el-Halebî'nin Mülteḳa'1Ebhur'udur. (Fahreddin Atar, "Mahkeme”, Türkiye Diyanet Vakfi İslam Ansiklopedisi (Ankara: TDV Yayınları, 2003), 27/342.) 
\begin{tabular}{l|l}
146 & Rizâeddin b. Fahreddin'in Yeni Mecelle Mücadelesi \\
RTEÜrFD &
\end{tabular}

faaliyetlerinde kadıların başvurduğu temel kabul edilmişti. İbâdât Mecelle'nin dışında bırakılınca, muamelâta (borçlar hukuku ile kısmen eşya, şahıs ve yargılama hukukuna dair hükümler) dair hususlar tedvîn edilmiştir. Bütün bunlarla birlikte Mecelle'yi düstûru'l-amel yapan devlet idaresinin "mûcebince amel oluna" iradesidir.

Konumuz gereği ele alacağımız Rusya Müslümanlarının Mecelle-i Ahkâm-1 Şer'iyye'si ile de hedeflenen yukarıda belirtilen özelliklere hâiz bir mecelle hazırlamaktır. Bizi bu kanaate Mecelle toplantısının tutanağında yer alan şu ifadeler sevk etmektedir: "Fetvâ kitaplarının çokluğu, onlarda bulunan rivayetlerin çeşitliliği, o kitapların Irak, Mâverâunnehir ve Hindistan gibi yabancı halkların hayat ve maişetlerine nazaran yazıldığından Rusya Müslümanları hayatına tatbiki çetinliği, gerek erbab-ı mahkeme için gerek etrafta bulunan ulemâ ve müderrisler için fetvâ bablarına iztırabını mûceb bula idi. (...) Hazırki zamanda düstûru'l-amel idilerek sika ve mu'temed mecelleye çok zamandır ihtiyaç-ı his kılına idi."

Rızâeddin b. Fahreddin, Rusya Müslümanlarının birçok probleminin hazırlanacak yeni Mecelle ile çözüleceğine inanmış ve bu doğrultuda sistematik bir mücadele vermiştir. Bu çalışmamızda, İslam hukuk tarihi açısından çok önemli olan Rizâeddin b. Fahreddin'in yeni Mecelle için verdiği mücadele sürecini ortaya koymaya çalışacağız.

\section{Rızâeddin b. Fahreddin'in Yeni Mecelle Düşüncesinin Oluşumu}

Rusya Müslümanları bağımsız devletleri oldukları dönemlerde genel itibariyle Hanefî mezhebine mensup olup, bu mezhebin doktrinleri çerçevesinde meselelerine çözüm bulmaya çalışmışlardır. Ancak işgal sonrası Rusya Müslümanları çeşitli nedenlerden dolayı İslam coğrafyasının diğer bölgelerindeki Müslümanlar kadar İslam hukuk kültüründen istifade edememiş ve birçok zorlukla karşılaşmışlardır. Bu zorluklar arasında; fıkıh kitaplarının temin edilememesi, kitapların basımının yapılamaması, kitaplar basılsa bile sansürlenmesi, kitapları anlayabilecek ilim

12 Rusya Müslümanlarmın İkinci Umumi Mahkeme-i Şer'iyye Tarafindan Daklad (Ufa: Şark Matbaası, 1917), 24. 
adamlarının olmaması ve bölgeye mahsus meselelerin ${ }^{13}$ fikıh kitaplarında yer almaması gibi çok önemli sorunları sıralamak mümkündür. ${ }^{14}$

Ancak bu genel sorunların yanında daha özel daha hassas bir husus vardı ki, bu da gerek Mahkeme-i Şer'iyye'ye seçilen/atanan kadıların ve gerekse aile hukuku çerçevesinde birinci derece mahkeme konumunda görev yapan mahalle imamlarının ilmi yetersizlikleridir. ${ }^{15}$ Yeterli derecede İslam hukuk kültürüne vâkıf olamayan görevliler sadece aile hukuku davalarına bakmış olsalar bile önlerinde müracaat edebilecekleri bir mecelleye şiddetle ihtiyaç duymaktaydılar. Dolayısıyla kazâ, yeni Mecelle'nin hazırlanmasını zorunlu kılan sorun olarak kendini göstermektedir.

Yukarıda sıralanan ve benzer diğer sorunları, görebildiğimiz kadarıyla bir bütün halinde ve yüksek sesle ilk kez dile getiren ve aynı zamanda çözüm önerileri de ortaya koyan kişi Rızâeddin b. Fahreddin'dir. Rızâeddin eğitimden ticarete, matbuattan kazâya kadar hemen her alanda çalışmalar yapmıştır. Ancak onun çalışmalarında, kazâ ve fetvâ sorunlarının çözümüne yönelik olmasının yanında eğitimde de önemli bir eksikliği gidereceğini düşündüğü geniş kapsamlı yeni bir mecellenin hazırlanması hususu daha önceliklidir.

Rızâeddin b. Fahreddin'in yeni Mecelle düşüncesinin kadılık görevine başladığı dönemle oluştuğu kuvvetle muhtemeldir. Çünkü kaleme alındığı tarih tam olarak

13 Bölgeye özel sorunların başlıcaları şu şekilde sıralanabilir: 1- Güneşin batmadığı günlere Ramazanın denk gelmesi durumunda iftar ve imsak vakitlerinin tespiti, orucun tutulup tutulmayacağı, 2- Güneşin batmadığı günlerde yatsı namazı, 3- Zekâtların okulların yapımı ve onarımı için kullanılıp kullanılamayacağı, 4- Gayrimüslim bir idare altında bulunan Müslüman bir topluluğun, Müslüman bir ülke ile savaşta nasıl bir tavır takınacağı, 5- Halifenin cihad ilan etmesi halinde bu çağrıya uyulup uyulmayacağı, 6- Kadınların örtünmesi (hicâb) ve benzeri sorunlar. [Bk. Musa Carullah, Kavâid-i Fıkhiyye (Kazan: Örnek Matbaas1, 1910); Musa Carullah, Uzun Günlerde Rûze (Kazan: Ümid Matbaası, 1911); Musa Carullah, Büyük Mevzularda Ufak Fikirler (St. Petersburg: M-A. Maksutova Matbaası, 1914); Şehâbeddîn Mercânî, Nâzûretü'l-Hakk fî Farziyyeti'l-Işâi ve In Lem Yeğibi'ş-Şafak, (Kazan: Şah Ahmed b. Hüsameddin Matbaası, 1287h.); Rızâeddin b. Fahreddin, Din̂̂ ve İctimâ̂ Meseleler, Çev. Ömer Hakan Özalp (İstanbul: Özgü Yayınlar1, 2007); Rusya Müslümanlarının İkinci Umumi Mahkeme-i Şer'iyye Tarafından Daklad v.d.]

14 Bahsedilen durumlara örnek olması açısından Troyskili Ahmed Taceddin'in şu ifadelerini aktarmak istiyoruz: “ . . kütüb-i fıkhiyyece olan kaht (kıtlık) ve gılâlleri (susuzluk) iki şeyden ileri geldiğine; onun da herkesin malumu olan Merkezi Hilafet-i İslamiyye uzak olmaları ve diyar-1 İslam'dan gönderilmiş kitapların Rus sansürlerinin gasb-1 mütehakkimânelerine maruz kalmaları idi." [Troyskili Ahmed Tâceddîn, "Rusya Müslümanları ve Üç Mesele" Strat-ı Müstakîm, $2 / 33$ (26 Mart 1325), 107.] Ayrıca Ahmed Taceddin, Câmiu'r-Rumuz'un (Şemsüddin Muhammed b. Husâmüddin el-Horasânî el Kuhistânî'nin, Hanefi mezhebinde mütûn-i erbe'a'dan olan Tacüşşeria'nın Vikâyetü'r-rivâyesine Sadrüşşeria'nın yazdığı en-Nukâye adlı muhtasarın şerhi) bazı yerlerde bir beygir (50 Ruble) fiyatına satıldığını, Muhtasaru'l-Vikâye'nin de ancak 1896 yılında ve cihâd babının da sansürleyerek basımının yapılabildiğini belirtmiştir. (Troyskili, "Rusya Müslümanları ve Üç Mesele", 107.)

15 Bk. Abdürreşit İbrahim, Çoban Yıldızı, 47-48. 
bilinmese de, Rızâeddin'in kadılığının ilk yıllarında yazdığını tahmin ettiğimiz Menâsıb-ı Diniyye adlı eserinde bu doğrultudaki düşüncelerini görmek mümkündür.

Rızâeddin Menâsıb-ı Diniyye'de, önce Avrupa hukuku ile İslam hukukunu kaynakları açısından kıyaslamaktadır. Bu kıyaslamaya göre Rızâeddin, Avrupa hukukunun aslen zayıf ve insanların saadetleri için yeterli olmasa da, kısmen mükemmel olduğunu buna karşılık İslam hukukunun aslen en muhkem hukuk olduğu halde aslına münasip bir dereceye henüz gelemediğini vurgulamaktadır. ${ }^{16}$

Rızâeddin'e göre Avrupa hukukunun kısmen de olsa mükemmel olmasının sebebi her zaman ve her yerde devlet idarecilerinin himayelerinde, uzmanlarından oluşturulmuş heyetler tarafından örf ve âdetler de dikkate alınarak hazırlanması ve düstûru'l-amel haline getirilmesidir. Rızâeddin Avrupa milletlerinin hukuklarının düstûru'l-amel olmasıyla yetinmediklerini, her gün eksiklik ve fazlalıkları gidermek için çalıştıklarını ifade etmiştir. Buna mukabil İslam hukukunun fakihlerin bireysel gayretleri sonucunda te'lif edilen birbirine benzer metotta çok fazla kitaptan ibaret olduğunu belirtmiştir. ${ }^{17}$ Rızâeddin'in bu düşüncelerinden, İslam hukukunun özündeki mükemmelliğe ulaşması için, bireysel çalışmalardan ziyade Avrupa hukukunda olduğu gibi kolektif bir sisteme geçilmesi arzusu açıkça anlaşılmaktadır.

Rızâeddin b. Fahreddin'i yeni Mecelle düşüncesine sevk eden sorunların en önemlilerinden biri de fetvâ meselesidir. Çünkü özellikle bölgeye mahsus günün sorunlarına dair hükümler/fetvâlar İslam hukuku kitaplarında ya yoktur ya da bu hükümleri bulmak ve anlamak zordur. Rıâeddin bu hususlara dair düşünceleri şu şekilde dile getirmiştir: "Bir at yükü olan fikıh kitaplarının içinde bugünde olan meselelerin üçten ikisine dâir malumât olunmadığı gibi yazılmış maddelerin de üçten ikisi bu asırlarda vücûd-î sûret tutmiyan ihtimallerdir."18

Rızâeddin b. Fahreddin'i yeni Mecelle düşüncesine götüren önemli sorunlardan biri de bütün fıkıh bölümlerinin aynı kitap içinde yer almasıdır. Rızâeddin yine Menâsıb-ı Diniyye'de, fıkhın bahisleri ve hükümlerinin bir hayli farklı olmasına rağmen hepsinin birlikte yazıldığını, artık her konunun ayrı ayrı te'lif edilmesi ve cüz'î meselelerin külli kâidelerin altında toplanmasının faydalı olacağını dile getirmiştir. ${ }^{19}$ Rızâeddin, böyle bir çalışmanın zorluğunun farkındadır ancak zaruretlerin mecbur bırakmasıyla insanın hayal dahi edemeyeceği şeyleri gerçekleştirebileceğine inancı tamdır. ${ }^{20}$ Rızâeddin tam bu noktada kedisine de cesaret verdiğini düşündüğümüz Osmanlı Devleti'nde Ahmed Cevdet Paşa başkanlığında




hazırlanan Mecelle-i Ahkâm-ı Adliye'nin çok güzel bir örnek olduğunu dile getirir. Rızâeddin, Mecelle'yi okuyan hiç kimsenin bunu inkâr edemeyeceğini, daha önce başka ülkelerde bir takım çalışmaların yapıldığını ancak bunların beklentileri karşılamadığını şu şekilde belirtmiştir:

“... Mecelletü'l-Ahkâmi'l-Adliye her ne kadar Kur'an ve sünnete tatbik cihetine riâyet idilmâmış belki, yalnız mezheb meslekî (yöntemi) riâyet idilûb yazılmış ise de, ilk bir kâide temhîd edilerek cüz'iyyâtını şundan çıkarabilmek yolları gösterilüb yazılmıştır. Örf, âdet ve dürüst (doğru) tecrübelere hem mümkün kadar muvâfakat riâyet idilmiştir. İşbu cihetten mezkûr eser îse daha güzelleri zuhûr idene kadar hüküm üstünde olanlar içün ziyade fâideli oldiğ̂̀ gibi hatta fikıh eliyle ülfet peyda etme arzusuyla tahsil iden şakirtlere ders iderek okutulmaya hem lâyıktır." 21

Rızâeddin bu ifadeleriyle, Mecelle-i Ahkâm-1 Adliye'nin hakkını teslim etmekle birlikte, özellikle sadece Hanefî mezhebi içtihatlarına göre hazırlanmış olmasının bir eksiklik olduğuna dikkat çekmektedir. Aynı zamanda Mecelle-i Ahkâm-ı Adliye'den daha güzellerinin hazırlanabileceği noktasında bir hedef de ortaya koymaktadır. Rızâeddin, hazırlanacak mecellenin bir kanun mecmuası olmasının yanında okullarda okutulacak bir ders kitabı olmasını da arzulamaktadır.

Rızâeddin b. Fahreddin'in yeni Mecelle düşüncesinin kadılık görevinin bir sonucu olduğuna dair önemli bir bilgi de 1905' de yapılan Ufa Kurultayı'nda sunduğu layihada yer alan şu ifadelerdir: "Hayli vakit Sobraniye (Mahkeme-i Şer'iyye)'de hizmet cihetiyle maişet-i kavmiyye ve ahlak-i millîyemize âşina oldum. Şakirtlerin, umumi âlemlerimizin tabiatlarına dair dersler okudum. Cüz'ine olsa da bir kadar nizam ve kanunlara vukûf kesbettim. Benim fikrime göre Sobraniye İdaresi'nin nizam maddelerine, şerîat esaslarına kılınan şu günkü düstûru'l-amellerini en acil ıslah lazımdır."22

Rızâeddin b. Fahreddin, Ufa Kurultayı'nda delegelerin Mahkeme-i Şer'iyye'nin nizâm yönünden sslah edilmesi taleplerini olumlu bulmakla birlikte şeriat açısından da 1slah edilmesinin önemini dile getirmiştir. Rızâeddin bu durumu, “Nizam cihetiyle beraber Sobraniye İdaresi (Mahkeme-i Şer'iyye)'nin düstûru'l-ameli olan fikıh kitaplarını da şeriat meselelerini de ıslah etmek elbette lazımdır" ${ }^{23}$ sözleriyle dile getirmiştir. Rızâeddin, eğer mahkemenin nizam yönü ıslah edilip de şerîat yönü ihmal edilirse beklenen faydanın meydana gelmeyeceğini de şu şekilde ifade etmiştir: "Nizam ciheti ıslah kılınıp da şerîat ciheti ıslah kılınmaz ise, bundan sonra gelecek kadılardan, reforme edilecek Sobraniye'den hemen fâide çıkmaz. Bizim halk, müftülerden, Sobraniye azâlarından şikâyet ederler. Doğrusu müftülerde de, azâlarda

21 Rızâeddin, Menâsıb-ı Diniyye, 60.

22 Carullah, Islahat Esasları, 53.

23 Musa Carullah, Islâhât Esasları (Petersburg: Tipografiya M.A. Maksutova, 1915), 53. 


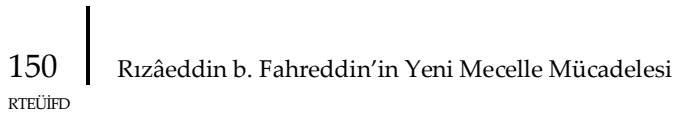

da günah vardır, kusur vardır. Lakin bütün kusur şahıslarda değil, yol doğru olmazsa en muktedir, en müstakim âdem de doğru hareket edemez." ${ }^{24}$ Bu düşüncelere sahip olan Rızâeddin aynı zamanda realitenin de farkındadır. Çünkü bu düşünce ve hizmetlerin gerçekleştirilebilmesi için ilim adamlarına ihtiyaç vardır. Fakat onun da, “... Öyle büyük hizmetlere müsteîd ehliyetli âdemler de gayet azdır” 25 şeklinde dile getirdiği gibi yeterince ilim adamının olmaması önemli bir sorun olarak kendini göstermektedir.

Rızâeddin b. Fahreddin gerek Menâsıb-ı Diniyye gerekse Ufa Kurultayı'nda ortaya koyduğu düşüncelerini 1906 yılında kaleme aldığ1 Rusya Müslümanlarının İhtiyaçları ve Onlar Hakkında İntikâd adlı risalesinde, özellikle aile hukukuna dair bir mecellenin hazırlanmasının dinî boyutuna vurgu yapmaktadır. Rızâeddin, Müslümanların aile meselelerine dair nizâların gayrimüslim bir hâkim tarafından halledilmesi İslam şerîatı açısından kuvvetsiz, bu kararların gayrimüslim mahkemelerde verilmesinin de temelsiz olduğunu vurgulamaktadır. ${ }^{26} \mathrm{Bu}$ ifadelerden anlaşıldığı üzere, Müslümanların bazıları aile nizâlarının halledilmesi için Rus mahkemelerine başvurmakta bu durum da Rızâeddin'i rahatsız etmektedir. Ancak Müslümanlar, Rus Devleti'nin tanıdığı haklar doğrultusunda aile hukukuna dair nizâlarda mahalle imamları veya Mahkeme-i Şer'iyye'ye başvurma hakları olduğu gibi Rus yerel mahkemelerine de başvuru yapabilmekteydiler. Müslümanları Rus yerel mahkemelerine sevk eden sebepler, Müslümanların Rus dilini öğrenmeleri, Ruslarla yakın ilişkiler kurmalarının yanında Rızâeddin'in de sıkça dile getirdiği gibi kadılar tarafından verilen birçok hükmün kabul görmemesi bulunmaktadır. Bu durum karşısında Rızâeddin'in çözüm önerisi ise, bölgedeki âlimlerden oluşturulacak bir cemiyet tarafından, fıkhın ta'dîl edilerek Müslümanların kendi örfüne muvafık, meseleleri halletmede düstûr (kanun), hâkimler için düstûru'l-amel olacak bir mecellenin hazırlanmasıdır. ${ }^{27}$

24 Carullah, Islâhât Esasları, 53-54.

25 Carullah, Islahat Esasları, 53.

26 Rızâeddin b. Fahreddin, Rusya Müslümanlarının İhtiyaçları ve Onlar Hakkında İntikâd (Orenburg: Kerimof Matbaas1, 1906), 32-33.

27 Rizâeddin, Rusya Müslümanlarının İhtiyaçları, 33.

Ayrıca Rızâeddin risalesinde sunduğu beş madde ile aile hukuku ekseninde yaşanan tartışmalar doğrultusunda durumun tespitini yaparak çözüm önerilerini daha somut bir şekilde ortaya koymuştur. Buna göre;

1) Aile meselelerini fasl etmeye fıkıh kitapları yeterli değildir,

2) Fıkıh kitaplarında olan bazı şeylerin icrası bu vakit bizlere mümkün değildir,

3) Bunların (fıkhı hükümlerin) zamanın iktizasına göre tağyir ve tebdilinin caiz olması,

4) Aile nizalarını fasl etmek umur-u diniyyeden olması,

5) Eğer hükümet teklif ederse düstûru'l-amel olmaya layık bir kitabın cem olunmasının lüzumu. (Rızâeddin, Rusya Müslümanlarının İhtiyaçları, 33.) 
Yukarıda özetlenen süreçte de görüldügü gibi, Rızâeddin b. Fahreddin'in ilk kadılık döneminin aynı zamanda yeni Mecelle düşüncesinin oluşmaya hatta olgunlaşmaya başladığı dönem olduğu söylenebilir. Rızâeddin, yeni Mecelle düşüncesini kadılıktan ayrıldıktan sonra da geliştirerek geniş kesimlere duyurmayı başarmıştır.

\section{Rızâeddin b. Fahreddin'in Yeni Mecelle'ye Yönelik Hazırlık Çalışmaları}

Rızâeddin b. Fahreddin hemen her fırsatta Müslümanların gelişimine katkı sağlayacak çalışmalar ortaya koymuştur. Rızâeddin'in yaptığı çalışmaların bazılarını zamanı geldiğinde adı konulacak yeni Mecelle için atılmış bir adım olarak değerlendirmek mümkündür. Bu nedenle Rıâeddin b. Fahreddin'in yeni Mecelle düşüncesini ortaya koyan bazı eserlerini ve kendisi tarafından yazılmasa da onun riyasetinde Musa Carullah tarafından hazırlanan Kavâid-i Fıkhiyye adlı eseri ele almak istiyoruz.

\subsection{Mutâlaa}

Mutâlaa, Rızâeddin b. Fahreddin'in ahund ${ }^{28}$ ve imamların kendi içlerinde cevap bulamadıkları ve Mahkeme-i Şer'iyye'den cevaplandırılmasını istedikleri sorulara verilen cevap ve fetvalardan özellikle nikâh hususunda olanlarını derleyerek hazırladığı risalesidir. İlk baskısının ne zaman yapıldığını bilemediğimiz Mutâlaa'nın, ikinci baskısına 1896-1903 yılları arası Mahkeme-i Şer'iyye'ye gönderilmiş sorulara verilen cevaplar/fetvalar ilave edilmiştir.

Eserde önce altı fâide yer almaktadır. Bu fâideler altında İslam yargı usûlüne ve bölgede aile hukukunun öne çıkan sorunlarına değinilmiştir. Sonraki bölümde ise, kısaca sorulara ve verilen cevaplara/fetvalara özet bir şekilde yer verilmiştir.29

Rızâeddin'in bu eseri bir kavâid/mecelle olmamakla birlikte, bölge özelinde aile hukukuna dair hususların Menâsıb-ı Diniyye'de dile getirdiği doğrultuda ${ }^{30}$ bir kitapta toplanması adına önemli bir çalışmadır. Bu şekilde Rusya Müslümanlarının aile hukukuna dair sorulan sorular ve verilen hükümler derlenerek Mahkeme-i Şer'iyye'ye bağlı bölgelere ulaştırılarak uygulamada birliğin sağlamasına önemli katkı sunulmuştur. Ayrıca sonraki aşamalarda bu hükümlerin kavâid/kanun formuna aktarılması da kolaylaşacaktır.

28 Yusuf Akçura Ahund'u şu şekilde tanımlamaktadır: Ahund payesi, mümtaz olan imamlara verilir. Bugün sahibine hiçbir hak ve vazife bahşetmeyen bir unvandan ibaret kalmış gibidir." [Sa'fes, "Rusya'da Sakin Müslümanların Mahalle ve Müftülük Teşkilatı" Türk Yurdu, 92/14 (10 Eylül 1331), 11.]

29 Bk. Rizâeddin b. Fahreddîn, Mutâlaa (Ufa: Fatih Kerimov Matbaası, 1321/1903).

30 Rızâeddin, Menâsıb-ı Diniyye, 59. 
\begin{tabular}{l|l}
152 \\
RTEÜIFD
\end{tabular} \mid Rizâeddin b. Fahreddin' in Yeni Mecelle Mücadelesi

\subsection{Tanzîmât}

Tanzîmât, Rizâeddin b. Fahreddin'in 1898'de, Mahkeme-i Şer'iyye tarafından muhtelif zamanlarda sorumluluk sahasındaki imamlar için yayımladığı fermanları derleyerek düstûru'l-amel haline getirdiği risalesidir. ${ }^{31}$ Rızâeddin söz konusu risalede resmi fermanlarının yanı sıra Rus Devleti'nin Müslümanlara yönelik kanunlarının bir kısmına da yer vermiştir. Risalenin en önemli kısmı, kazâ görevini yerine getiren kadılar ve imamlar için Mecelle-i Ahkâm-ı Adliye'den de bazı bölümlerin ilave edilmesiyle Hanefî mezhebi ekseninde hazırlanan İslam aile hukukuna dair 54 maddelik bölümdür. ${ }^{32}$

Rızâeddin b. Fahreddin, her ne kadar aşikâre dile getirmese de Tanzîmât adlı eseri ile yeni Mecelle yolunda önemli bir adım atmıştır. Mutâlaa'da çerçevesi çizilip genel bir şekilde ifade olunan hususların Tanzîmât'ta kanun formatına aktarıldığını görmekteyiz. Böylece Rızâeddin Mahkeme-i Şer'iyye' de kadı olmanın avantajı ile hem mahkemeye çeki düzen vermiş hem de mahkemenin arşivinden yararlanarak yeni Mecelle yolunda önemli çalışmalar yapmıştır.

\subsection{Dinî ve İctimaî Meseleler}

Rızâeddin b. Fahreddin' in 1914'te yayımlanan usûl-i fıkıh tarzında kaleme aldığı eseridir. Yazar genel itibariyle, dinî ve toplumsal meselelere usûl açısından bir yaklaşım ortaya koymuştur. Rızâeddin, bu eserinde de güçlü bir şekilde İslam şeriatının kanunlaştırılmasını şu şekilde dile getirmektedir. "Kur'an-ı Kerim insanlardan ayrı-uzak kalmasın ve İslam şerîatının yerine Fransız kanunları geçmesin deniliyorsa, yukarıda söylediğimiz şekilde davranma zorunluluğu vardır; çünkü İslam dini salt amel ya da salt itikattan ibaret değildir; bununla birlikte bir kanun, hukuk, ahlak düstûru ve bir hayat nizamıdır." 33

Musa Carullah, Rızâeddin'in bu eserini çok beğenmiş olmakla ${ }^{34}$ birlikte bir intikâd (tenkîd) yazmıştır. Bu intikâd Mülahaza adıyla bir risale olarak basılmıştır. Diğer taraftan Carullah'ın bu intikâdı, editörlüğünü Rıâeddin b. Fahreddin'in yaptı̆̆ Şûrâ dergisinde büyük bir memnuniyetle yayınlanmıştır. ${ }^{35}$

\footnotetext{
31 Rızâeddin b. Fahreddîn, Tanzîmât (Kazan: Dombravski'nin Basımhanesi,1898), 1-2.

Rızâeddin, Tanzîmât, 34-39.

33 Rizâeddin b. Fahreddin, Din̂̂ ve İctimâ̂ Meseleler, çev. Ömer Hakan Özalp (İstanbul: Özgü Yayınları, 2007), 143.

34 Bk. Musa Carullah Bigiyef, Mülâhaza (Petragrad: Maksudof Matbaası, 1914), 2-3.

35 Rızâeddin b. Fahreddîn, "Dinî ve İctimaî Meseleler", Şûrâ, 7/24 (11 Safer 1333), 766.
} 


\subsection{Yeni Mecelle'ye Medhâl: Kavâid-i Fıkhiyye}

Rızâeddin b. Fahreddin'in yeni Mecelle düşüncesinin en somut adımı Musa Carullah tarafından 1910 yılında kaleme alınan Kavâid-i Fıkhiyye'dir. Bu eseri her ne kadar Carullah hazırlamışsa da, fikir ve desteğin Rızâeddin b. Fahreddin'den geldiği bizzat kitabın kapak sayfasında yer almaktadır.

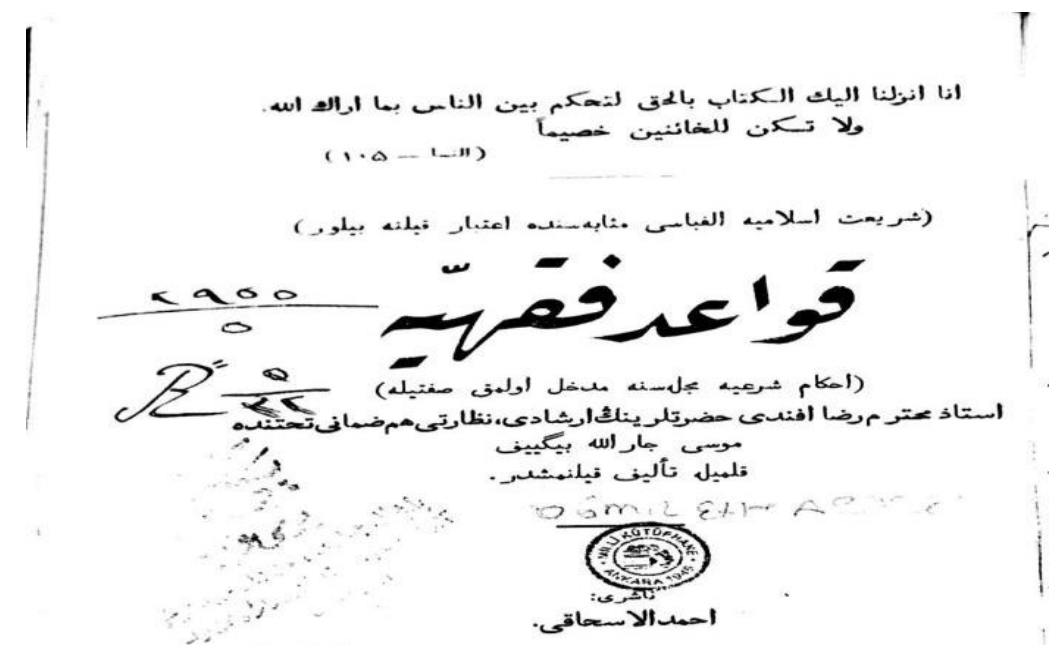

Kavâid-i Fıkhiyye'nin kapak sayfasında "Şerîat-1 İslamiyye elif-bâsı mesâbesinde i'tibar kılınabilir" ifadesi kullanılmış kitabın isminin altına da "Ahkâm1 şer'iyye mecellesine medhâl olmak sıfatıyla" kaydı düşülmüştür. Ayrıca yine bu sayfada "Üstâz Muhterem Rızâ Efendi hazretlerinin irşâd-ı nezâreti hem damânı tahtında" 36 ibaresi kitabın Rızâeddin b. Fahreddin'in gözetimi altında yazıldığını açıkça göstermektedir.

Rızâeddin b. Fahreddin ile Musa Carullah arasında birçok açıdan hedef birliğinin yanı sıra büyük bir dostluk vardır. Bu dostluğa binaen Rıâeddin'in hayali olan yeni Mecelle'ye medhâl olacak külli kâidelerin yazımını, hukukçu özelliği de dikkate alınarak Carullah'a verdiğini söyleyebiliriz. Mahkeme-i Şer'iyye'nin devamı niteliğinde olan Rusya Müslümanları Merkezi Dini Nezareti'nin Türkiye Temsilcisi Cafer Sadık Özlevent ile 4 Şubat 2007' de İstanbul'da Rusya Müslümanları üzerine yaptığım görüşmede, "Biz millet olarak gençleri kendimize tercih ederiz ve onların yolunu açarız" ifadelerini kullanmıştı. ${ }^{37}$ Kavâid-i Fıkhiyye'de de tam olarak bu durumu

36 Musa Carullah, Kavâid-i Fıkhiyye (Kazan: Örnek Matbaası, 1910), 1.

37 Benzer bir durum 2015 yılında Rusya Müslümanları Merkezi Dini İdaresi Başkanı Talgat Taceddin'in, "Rusya Müftüsü" unvanını, 28 yaşındaki Tataristan Müslümanları Diyanet İşleri Başkanı Kamil Samigullin'e devretmesinde görülmektedir. [Türkrus, "Rusya'da 23 yıllık müftü görevi devretti, ama Müslüman örgütleri birleşemedi” (Erişim 27 Mart 2021) https://www.turkrus.com/145365-rusyada-23-yillik-muftu-gorevi-devretti-ama-muslumanorgutleri-birlesemedi--xh.aspx] 


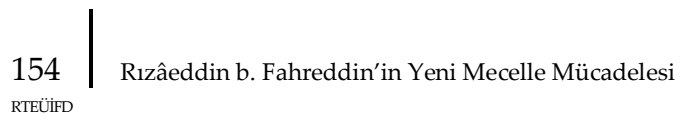

görmekteyiz. Rızâeddin, hukuk ilmine kendinden daha vâkıf ve daha genç olan Carullah'ı destekleyerek yeni Mecelle düşüncesini hayata geçirmek adına çok önemli bir adım atmıştır.

Carullah, Kavâid-i Fikhiyye'de, 99'u Mecelle-i Ahkâm-1 Adliye'den alınan toplamda 201 madde derlemiştir. Genel itibariyle Hanefî mezhebi içtihatlarının derlendiği eserde, bazı maddelerde (mevkûd meselesi gibi) diğer mezheplerin görüşlerinin benimsendiği, bazı maddelerde de (kölelik meselesi gibi) Carullah'ın içtihat ettiği görülmektedir.

\section{Yeni Mecelle'nin Resmen Projelendirilmesi ve Te'lif Usûlü}

Rusya Müslümanları, Şubat 1917 İhtilali sonrasında Mahkeme-i Şer'iyye merkezli hızlı bir şekilde kongreler düzenlemeye başladılar. 15-22 Haziran 1917 (9-15 Ramazan 1335) tarihinde de din adamları dinî meseleleri görüşmek üzere Ufa'da toplandilar. Umûru Diniyye ve İlmiyye hususunda müşavere için Mahkeme-i Şer'iyye huzurunda toplanan ulemâ, Rusya Müslümanları için Mecelle-i Ahkâm-ı Şer'iyye adıyla yeni Mecelle'nin hazırlanmasının zarureti hakkında büyük bir ittifak oluşturmuşlardır. Şunu belirtmek gerekir ki, ulemâ tarafından yeni Mecelle fikrinin kısa zamanda büyük bir konsensüs ile kabul görmesinde Rızâeddin b. Fahreddin'in çalışmalarının çok büyük etkisi vardır. Buradaki başarının büyüklüğü, Osmanlı Devleti'nde Mecelle'nin hazırlanması aşamalarında ortaya konulan muhalif direnç ile karşılaştırıldığında açık bir şekilde görülebilir.

Yeni Mecelle'nin ivedilikle hazırlanması kararını alan Mahkeme-i Şer'iyye, zaman kaybetmeden çalışmalara başlamıştır. Hazırlanacak mecellenin te'lif usulü belirlenmiş ve Mecelle Télif Heyeti oluşturulmuştur. Ayrıca yeni Mecelle'nin tamamlanma süresi ve masraflarının nasıl karşılanacağına kadar ilgili hususlar da karara bağlanmıştır. Bu toplantı ile yeni Mecelle'nin adı, daha önce Kavâid-i Fıkhiyye'de gayri resmi ifade olunduğu gibi Mecelle-i Ahkâm-ı Şer'iyye ${ }^{38}$ olarak belirlenmiştir. ${ }^{39}$

38 Mecelle-i Ahkâm-1 Şer'iyye'nin Osmanlı Devleti'ndeki Mecelle-i Ahkâm-ı Adliye' den farklı olarak "şer'iyye" olarak adlandırılmasının muhtemel üç sebebi bulunmaktadır. Bunlardan birisi, Mecellei Ahkâm-1 Adliye komisyonunun Dîvân-1 Ahkâm-ı Adliyye Nâzırı Ahmed Cevdet Paşa'nın başkanlığında bu kurumun bünyesinde oluşturulmasından dolayı nezâretin adı Mecelle'ye yansıtılmıştır. Benzer şekilde Mecelle-i Ahkâm-1 Şer'iyye de Mahkeme-i Şer'iyye'nin bünyesinde oluşturulan bir komisyon tarafından hazırlanacak olmasından dolayı bu şekilde adlandırılmış olabilir. İkincisi, Mahkeme-i Şer'iyye'ye tanınan yargılama sahası aile hukuku ile sınırlı tutulmuştur. Bu durum Osmanlı Devleti'nde Tanzimat'ın ilanı sonrası şer'iyye mahkemelerinin durumuna benzemiş olmasından dolayı böyle bir adlandırma yapılması muhtemeldir. Üçüncü olarak da, Mecelle için Adliye veya benzeri bir adlandırmanın Rusya'nın dikkatini bu yöne çevirmesine sebebiyet vermesi muhtemel olduğundan ve Rusya Müslümanlarının bulunduğu ortam itibariyle mümkün görülmemektedir.

39 Daklad, 24-25. 


\subsection{Mecelle'nin Te'lif Usûlü}

Komisyonun Mecelle-i Ahkâm-1 Şer'iyye için uygun gördüğü usûl, ana hatlarıyla şu şekilde sıralanabilir. ${ }^{40}$

1) Mecelle-i Ahkâm-1 Şer'iyye, Kur'an-1 Kerim ve Sünnet esas tutularak te'lif edilecektir.

2) Ulaşım ve uygulamada kolaylık olması açısından bölgede bulunan Hanefî mezhebi kitaplarından en güvenilir olanlar kaynak olarak kullanılacaktır.

3) Hanefî kitaplarında yeterince açık olmayan meseleler Mâlikî, Şâfiî ve Hanbelî fıkhı kitaplarından alınacaktır.

4) Bazı hâdiselerde, zaman ve duruma göre Hanefî mezhebi dışındaki ehl-i sünnet mezheplerinin içtihatları daha münasip görülürse o içtihatlar alınacaktır.

5) Mezheplerde hükmü bulunmayan veya bulunan hükmün tatbiki mümkün görülmeyen meseleler olursa, te'lif heyeti usûl-i şer'iyyeden istinbat ve istihraç hakkına sahip olacaktır. Télif heyetinin çözüme kavuşturamadığı meseleler olduğunda ilgili âlimlere müracaat edilecektir.

6) Fikhî meselelerin mümkün olduğunca Avrupa hukukuna intibakı istenmiş olduğundan gerekli görüldüğünde meclise Avrupa hukuku âlimleri de çağırılıp istişare edilecek ve rivayetler arasında Avrupa hukuku ile en iyi uyuşanı tercih edilecektir.

7) Mecelle Heyeti tarafından hazırlanacak metnin tebdil ve ıslahı Kazan'da kurulacak Lecne-i İlmiyye'de yapılacaktır. ${ }^{41}$

8) Mecelle-i Ahkâm-1 Şer'iyye tamamlandığında Mahkeme-i Şer'iyye'de ulemâ cemiyeti tarafından muhakeme edilip tasdik edilecektir.

Mecelle-i Ahkâm-1 Şer'iyye'nin te'lif usûlünde de Rızâeddin b. Fahreddin'in etkisi açıkça görülmektedir. Zira Rızâeddin'in Rusya Müslümanlarının İhtiyaçları ve Onlar Hakkında Intikâd adlı risalesinde yukarıda sıralanan hususların hemen hemen hepsi yer almaktadır. Mecelle-i Ahkâm-1 Şer'iyye'nin te'lif usulünün en temel noktasını eklektik usûl üzere projelendirilmesi oluşturmaktadır. Projeye temel teşkil eden bu düşüncenin yaklaşık on yıl önce Rızâeddin tarafından, “... Hiçbir mezheple mukayyed olmaz, belki oldukça usûl-i şeriâta tatbik ederek yazılması münasip olur. Her mezhebin kitapları toplanır ve her birinden münasip olanı alınıp münasip olmayanı terk edilir." ${ }^{22}$ şeklinde ifade edilmesi, onun bu çalışma üzerinde etkisinin ne denli önemli olduğunu ortaya koymaktadır.

Rızâeddin b. Fahreddin'in yıllar önce dile getirdiği usûl doğrultusunda Mecellei Ahkâm-ı Şer'iyye'nin projelendirilmesi onun aynı zamanda İslam dünyası ve

40 Daklad, 24-25.

41 Daklad, 24-25.

42 Rizâeddin, Rusya Müslümanlarının İhtiyaçları, 43-44. 
özellikle Osmanlı ile ne kadar irtibatlı olduğunu da göstermektedir. İslam hukukunda, Mecelle-i Ahkâm-1 Adliye ile başlayan yeni dönemle birlikte, yeni çalışmalar, yeni düşünceler ortaya çıkmaya başlamıştır. Mecelle-i Ahkâm-ı Adliye'nin yürürlüğe girmesinden kısa bir zaman sonra Mecelle'nin ta'dil edilmesi de bu çalışmalardan birisidir. Mecelle'nin ta'dil düşüncesinin gündeme gelmesiyle en çok dillendirilen husus herhalde Hanefî mezhebi dışındaki mezheplerin içtihatlarından yararlanılma yoluna gidilmesinin gerekliliği olmuştur. Örnek olarak Elmalılı Hamdi Yazır kaleme aldığı makalede, İslam' da muteber bütün mezheplerin dikkate alınarak geniş bir heyet-i ilmiyenin teşkil edilmesini, ortaya konan meselelerde önce Hanefî mezhebinin tercih edilmesini, eğer Hanefî mezhebinde bulunmayan bir mesele olursa diğer mezhep içtihatlarının alınması gerektiğini ifade etmiştir. Hatta Yazır, İslam hukuku içinde çözüm bulunamayan bir meselenin tesadüf etmesi halinde Avrupa hukukundan da yararlanılması gerektiğini ve bu şekilde hazırlanacak bir mecellenin âleme parmak ısırtacak bir güzellikte olacağı iddiasındadır. ${ }^{43}$

Osmanlı ve Cumhuriyet dönemi hukukçularından Ebul'ulâ Mardin de Mecellei Ahkâm-1 Adliye'nin sadece Hanefî mezhebi hükümleri çerçevesinde hazırlanmasının onu daralttığını belirterek “ (...) Hâlbuki hükümleri dar bir çerçeve içinde Hanefì mezhebi hükümleri ile iktifa cihetine gidildi. Ve iç siyaset endişesi ile ihtiraz ve tehaşi mesleki güdüldü. İste bu yüzden Malikî mezhebindeki alacă̆ın temliki ve borcun nakli gibi Roma hukukunda bile bulunmayan ve ilk olarak tedvîni Alman Medenî Kanununa bir fahrü şeref vesilesi veren hükümlerden faydalanma fırsatı kaçırıldı." 44 ifadeleriyle İslam hukuk kültürünün zenginliğinin Mecelle'ye yansıtılmasının ona katacağı değeri dile getirmiştir.

Yukarıda zikredilen düşünceler, Osmanlı Devleti'nde 1917 yılında hazırlanan Hukuk-i Âile Kararnâmesi ile meyvelerini vermiştir. Zira Hukuk-i Âile Kararnamesi'nde kanunlaştırma tekniği açısından eklektik bir metot tercih edilerek sadece Hanefî mezhebine bağlı kalınmayıp diğer mezheplerden de faydalanılması usûlü takip edilmiştir. ${ }^{45}$

Yukarıda söz konusu edilen düşünceleri ve uygulamaları dikkate aldığımızda, Mecelle-i Ahkâm-1 Şer'iyye' de kabul gören usûlde de olduğu gibi, bir mezhebi temel kabul edip diğer mezhep içtihatlarını da dikkate alarak eklektik bir yöntem uygulanması bir bölgeye has olmaktan ziyade dönemin bir ihtiyacı olduğu anlaşılmaktadır. Rızâeddin b. Fahreddin'in de bu ihtiyacı ilk dile getirenlerin ve bu

43 Küçük Hamdi (Elmalılı Hamdi Yazır), "Makâle-i Mühimme”, Beyânü'l-Hak, 1/18 (9 Muharrem 1327), 403.

44 Ebul'ulâ Mardin, Medeni Hukuk Cephesinden Ahmet Cevdet Paşa (Ankara: TDV Yayınları, 2009), 171.

45 Aydın, Mehmet Âkif, "Hukuk-1 Âile Kararnamesi", Türkiye Diyanet Vakfı Ansiklopedisi, (İstanbul: TDV Yayınları, 1998), 18/314-318. 
doğrultuda bir mücadele ortaya koyanların başında geldiğini rahatlıkla söylemek mümkündür.

\subsection{Mecelle Te'lif Heyeti}

Mecelle-i Ahkâm-1 Şer'iyye'yi te'lif etmek için oluşturulan komisyon şu kişilerden oluşmuştur.

1) Âlimcan Hazret Bârûdî

Müftü

(Kazan )

2) Rızâeddin b. Fahreddin

Kadı

(Samara)

3) Hasan Atâ Abeşî

Kadı

(Kazan)

4) Necib Tentûrî

Âlim

(Tunter)

5) Ziyâeddin Kemâlî

Yazar

6) Mûsa (Carullah) Bigiyef

Âlim

(Rostov)

7) Murâd Mekkî

Âlim

8) Sâlihcân Ormanef

Kadı

9) Hüccetü'l-Hakîm Mahmudef

Kadı

(Sibirya)

10) Sâbir Hasanef

Müderris

(Orenburg)

Mecelle Te'lif Heyeti'nin en önemli üyelerinden birisi hiç şüphesiz Rızâeddin b. Fahreddin'dir. Bu durum komisyonun teşekkülünde, Mahkeme-i Şer'iyye'nin Müftüsü ve komisyonun doğal başkanı konumunda olan Âlimcan Bârûdî'den sonra Rızâeddin b. Fahreddin'in yer almasında açıcça görülmektedir. Rızâeddin b. Fahreddin'in yaklaşık yirmi yıl boyunca her geçen gün biraz daha olgunlaştırdığ Mecelle düşüncesi, bu düşünce etrafında yaptığı çalışmaları, kadılık görevinde edindiği tecrübeler ve ceditçi bir düşünceye sahip olması, onu Te'lif Heyeti'nin en önemli kişisi konumuna getirmiştir.

\section{Yeni Mecelle (Mecelle-i Ahkâm-ı Şer'iyye) Projesinin Sonucu}

Rusya'da yaşanan Şubat 1917 Devrimi Müslümanlar için özgürlüklerin önünü açmıştır. Mahkeme-i Şer'iyye özerk bir yapıya kavuşmuş ve artık Müslümanlar var olan haklarının6 yanı sıra mahkemenin müftü ve kadılarını seçme hürriyetine

46 Yusuf Akçura Rusya Müslümanlarının sahip olduğu hakları şu şekilde dile getirmiştir: "Rusya devletine tabi Müslümanlar pek sınırlı bazı umur-u kazâiyye-i diniyye ile umur-u diniyye sarfında bir nevi muhtariyete haizdirler: Doğum, vefat, nikâh, talak miras, ibadete ve merasim-i diniyyeye riyaset (imamlık) ve bir dereceye kadar talim ve tedris (Bilhassa dini okutmak) işleri kendilerine bırakılmıştır. Bu vazifeleri ifa etmek üzere Müslümanların müezzinleri, imamları, hatipleri, muallimleri, müderrisleri, ahundları, kadıları, müftüleri vardır. Müslümanlar, bilfiil bir cami etrafında bir mahalle teşkil ederler, mahallenin reis-i diniyyesi İmamdır. Müezzin ona 
kavuşmuşlardır. Mahkeme-i Şer'iyye'nin kurumsal yapılanmasının tamamlanmasının hemen ardından 15-22 Haziran'da ilk iş olarak Rızâeddin b. Fahreddin'in yaklaşık yirmi yıl önce altyapısını oluşturmaya başladığı yeni Mecelle düşüncesi Mahkeme-i Şer'iyye tarafından Mecelle-i Ahkâm-ı Şer'iyye adıyla resmen projelendirilmiştir. Mahkeme-i Şer'iyye huzurunda yapılan toplantılarla hazırlanacak Mecelle' nin gerekçesi açıklanmış, usûlü belirlenmiş, hedeflenen tamamlanma zamanı projelendirilmiş ve te'lif heyeti oluş̧urulmuştur. ${ }^{47}$

Yeni Mecelle açısından, projesinin tüm yönleriyle ortaya konulduğu Ufa'daki toplantıdan yaklaşık bir ay sonra 18-26 Temmuzda Kazan'da; Kırım, Kafkasya, Türkistan, Kırgızistan, Sibirya ve İdil bölgesinden iki yüzün üzerinde din adamının iştirak ettiği Bütün Rusya Müslümanları Ulema Kongresi de önemli bir aşamadır. Bu kongrede her ne kadar Mecelle-i Ahkâm-1 Şer'iyye projesi somut olarak ele alınmasa da Rusya Müslümanları için böyle bir çalışmanın yapılmasının gerekliliğine vurgu yapılmıştır. Tigiz adıyla, Ehl-i Sünnet mezheplerin içtihatları dikkate alınarak zamanın şartlarına muvafık din görevlileri için el kitabı mahiyetinde olacak bir mecellenin hazırlanması gerekli görülmüştür. ${ }^{48}$

Bütün Rusya Müslümanlarının Mecelle-i Ahkâm-ı Şer'iyye projesine destek vermesi büyük bir motivasyon meydana getirmiştir. Ancak Ekim 1917'deki Bolşevik Devrimi bütün bu çalışmalara ağır bir darbe indirmiştir. Devrimciler her ne kadar Mahkeme-i Şer'iyye’yi lağvetmemişseler de, özellikle 1905 sonrası Rusya Müslümanlarının elde ettiği kazanımların çoğunun yitirilmesine sebebiyet vermişlerdir. Devrim sonrası Rusya'da yaşanan siyasi ve ekonomik krizler her geçen gün ağırlaşmış ve herkesi olduğu gibi Müslümanları da ağır bir şekilde etkilemiştir. Özellikle 1920 sonrası hemen herkes bütün güçleriyle açlık felaketi ile mücadele etmek zorunda kalmıştır. ${ }^{49}$

Müslümanlar açısından iç karışıklıklar ve açlık felaketi öylesine etkili olmuştur ki, Müftü Âlimcan Barûdî'nin 1921 yılında vefatı sonrası yaklaşık iki yıl kadar

muavenete bulunur. İmamların çoğunluğu hatip, birçoğu müderris olduğu gibi bazıları da Ahund unvanına haizdir. Mahalle camilerinin çoğunun yanında bir mahalle mektebi, bazılarının yanında mahalle mektepleriyle beraber bir medrese mevcuttur. Muallim (Bazen müezzinler muallimlik ederler) mektebin, medresenin üstaz ve müdürüdür. Ahund payesi, mümtaz olan imamlara verilir. Bugün sahibine hiçbir hak ve vazife bahşetmeyen bir unvandan ibaret kalmış gibidir." [Sa'fes, "Rusya'da Sakin Müslümanların Mahalle ve Müftülük Teşkilatı” Türk Yurdu, 92/14 (10 Eylül 1331), 11.]

47 Daklad, 24-27.

48 Nadir Devlet, 1917 Ekim İhtilali ve Türk-Tatar Millet Meclisi (İstanbul: Ötüken Neşriyat, 1998), 239240; İbrahim Maraş, "Kazan Bölgesinde Yeni Mecelle Çalışmaları", Uluslararası Mecelle Sempozyumu, ed. Mustafa Artuç vd. (Ankara: Türkiye Adalet Akademisi Yayınları, 2017), 284.

49 Türkoğlu, Rizâeddin Fahreddin, 252-263. 
Mahkeme-i Şer'iyye' ye yeni bir müftü bile seçilememiştir. Bu süre içinde Rıâeddin b. Fahreddin vekâleten müftülük görevini yürütmüştür.

Rızâeddin b. Fahreddin, 1923 yılında Rusya Müslümanlarının yoğun talebi sonucu vekâleten yürüttüğü müftülük görevine seçimle getirilmiştir. Bu seçim aynı zamanda yeni Mecelle projesi için de yeni bir umut ş̧ığı olmuştur ve yeniden bir projelendirme yapılmıştır. Ancak dönemin siyasi atmosferinden olsa gerek, Mecelle-i Ahkâm-1 Şer'iyye projesi farklı bir usûl ile hayata geçirilmek istenmiştir. Bu husustaki bilgilere, Rusya Türkleri üzerine çok sayıda araştırma yapan ve uzun süre bu bölgelerde kalan İbrahim Maraş'ın çalışmalarından ulaşmaktayız. Maraş, çalışmaları esnasında Şehâbeddin Mercani'nin öğrencilerinden Abdurrahman Ömerî tarafından Mecelle-i Ahkâm-1 Şer'iyye'nin aile hukuku bölüme dair 551 maddeden ibaret el yazması bir esere ulaşmıştır. ${ }^{50}$

İbrahim Maraş'ın ifadelerinden anlaşıldığına göre; Dinî Nezâret ${ }^{51}$ nezdinde Temmuz 1924'de oluşturulan Ulema Şûrası'nın yaptığı toplantı Mecelle için yeni bir başlangıç olmuştur. Şûrada Mecelle-i Ahkâm-1 Şer'iyye konusu görüşülerek yeni bir usûl ile devam edilmesi kararlaştırılmıştır. Buna göre, Mecelle çalışmalarının bir komisyon tarafından değil de, konunun uzmanı sayılan kişiler tarafından bölümler halinde yazılması uygun görülmüştür. Şûrada Mecelle'nin hangi bölümlerinin ve bu bölümleri yazma görevinin kimlere verildiği hakkında aile hukukuna dair bölüm dışında bugün için elimizde bir bilgi mevcut değildir. ${ }^{52}$ Mecelle'nin aile hukukuna dair bölümünün Abdurrahman Ömerî’ye verildiği bilgisi ise mevcut ve kesindir. Abdurrahman Ömerî̀nin aile hukukuna dair hazırladığı bölüm, "Mecelle-i Ahkâmı Şer'iyye'nin Ailege Aid Kısmı" adıyla 1926 yılında 551 madde olarak tamamlanmış ve Ulema Şûrası'na sunulmuştur. Bu çalışma, Ulema Şûrası tarafından onaylanarak basılma kararı verilmiştir. Aile hukukuna dair bölümün basılma kararı alınmış olmasına rağmen bugüne kadar bu çalışma basılmamıştır. ${ }^{53}$

Yine Maraş'ın ifade ettiğine göre, Mecelle-i Ahkâm-1 Şer'iyye'nin Abdurrahman Ömerî tarafından hazırlanan aile hukukuna dair bölümü genel itibariyle Hanefî mezhebi esas alınarak hazırlanmıştır. Ancak çok zaruri durumlarda Hanefî mezhebi dışındaki mezheplerin içtihatlarına başvurulması kararlaştırılmıştır. ${ }^{54} \mathrm{Bu}$ ifadelerden de anlaşıldığı üzere Rızâeddin b. Fahreddin'in, Mecelle' nin sadece Hanefî mezhebinin

\footnotetext{
50 Maraş, “Kazan Bölgesinde Yeni Mecelle Çalışmaları”, 285-286.

51 Ekim 1917 Bolşevik İhtilali sonrası Mahkeme-i Şer'iyye'nin adı "Dinî Nezaret" olarak adlandırılmıştır.

52 Rusya (SSCB)'deki rejim değişikliği Müslümanlar üzerinde etkisini ağır ağır göstermiştir. 1932 yılında ne kadar el yazma veya basma Arapça eser varsa toplatılarak imha edilmiştir. (Türkoğlu, Rızâeddin Fahreddin, 282.) Bu nedenle çok nadir olarak bazı kitaplar günümüze ulaşmıştır.

53 Maraş, "Yeni Mecelle Çalışmaları", 285.

54 Maraş, "Yeni Mecelle Çalışmaları", 287.
} 


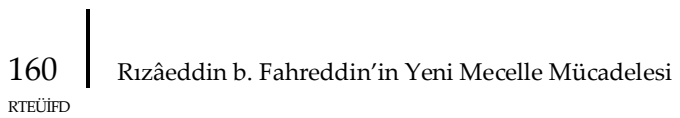

içtihatları doğrultusunda hazırlanmasını istemesinin veya onaylamasının içinde bulunulan şartlarının ağırlığından kaynaklandığını düşünmekteyiz. Çünkü Rızâeddin'in çok mücadele verdiği telfîkçi metottan kolay kolay vazgeçmesi pek mümkün görülmemektedir. Zor şartlar altında hızlı bir şekilde hayata geçirilebilecek bir Mecelle hazırlanması için kolay ulaşılabilir olması hasebiyle Hanefî mezhebinin tercih edildiğini tahmin etmekteyiz.

Mahkeme-i Şer'iyye Bolşevik İhtilaliyle ciddi sarsıntılar geçirip, zaman zaman sembolik bir kurum haline gelse de varlığını korumayı başarmıştır ve günümüzde Ufa'da Rusya Müslümanları Merkezî Dinî Nezareti adıyla varlığını devam ettirmektedir. Ancak yukarıda özetlediğimiz sürecin dışında Mecelle-i Ahkâm-ı Şer'iyye projesinin veya benzer bir çalışmanın gündeme getirildiğine dair her hangi bilgiye rastlamadık. Rızâeddin b. Fahreddin'in kadılığı sırasında fikrini ortaya attığı, her geçen gün olgunlaşması için adım adım mücadele ettiği yeni Mecelle mücadelesi Rusya Müslümanları için bir heyecan meydana getirmiştir. Ancak beklenmedik hâdiselerin yaşanması bu mücadeleyi önce sekteye uğratmış sonra da tamamen akîm bırakmıştır.

Yeni Mecelle projesinin akîm kalmasının sebeplerinin daha iyi anlaşılması için Müftü Rizâeddin b. Fahreddin'in 7 Mart 1926'da Abdürreşid İbrahim'e yazdı̆̆ mektuptan kısa bir bölüm aktarmak istiyoruz: “(...) may 30'ında İslam nedvesi cıyılü üçün Hükümet izin birdi. Kütülmegen maniler zuhur itmese cryllur. Lâkin bizinğ üz halkımızda fikir, himmet, ahlâk ve hamiyyet kabilinden şeyler iflas etti. Aramızdagı ihtilâf ve iftirak künden-kün artup ve küçlenüp baradır."55 Rıâeddin'in bu ifadeleri, Rusya Müslümanlarını bir arada tutan değerlerin kaybolduğu, bu durumun da kendisini umutsuzluğa sürüklediğini göstermektedir. Rızâeddin'in aynı mektupta, Müslümanların birbirleriyle olan münasebetlerini kıyamet günü yaşanacak manzara ${ }^{56}$ ile tasvir etmesi, durumun vahametini daha net bir şekilde ortaya koymaktadır. Yaşananlar Rıâeddin b. Fahreddin'i, büyük mücadeleler verdiği toplumunu bile terk etmeyi düşündürmüştür. ${ }^{57}$ Zaten Türkoğlu'nun ifadesiyle bu dönemde Din̂̂ Nezâret de, bütün işlevleri elinden alınmış sadece yabancı ülkelere karşı şeklen gösterilen bir kurum haline getirilmişti. ${ }^{58} \mathrm{Bu}$ şartlar altında çok büyük bir proje olan Mecelle-i Ahkâm-1 Şer'iyye'nin hazırlanması mümkün olmamıştır.

\section{SONUÇ}

Rusya Müslüman âlimlerinin önde gelenlerinden Rizâeddin b. Fahreddin, birçok alanda verdiği mücadelelerin yanı sıra, Rusya Müslümanlarına gayrimüslim hukuk ve yargı sisteminin dayatılmasına karşı çıkmış, buna mukabil

55 Taymas, Kazanlı Türk Meşhurlarından Rızâeddin Fahreddin, 54.

56 el-Abese 80/34-36.

57 Taymas, Kazanlı Türk Meşhurlarından Rızâeddin Fahreddin, 54-55.

58 Türkoğlu, Rızâeddin Fahreddin, 284. 
Müslümanlarının özellikle de aile hukukuna dair meselelerde kendi hukuk ve yargı sisteminin uygulanmasını güçlü bir şekilde savunmuştur. Rızâeddin'e göre; hem Müslümanların kendi hukuk sistemini hâkim kılmaları hem de kadılar arasında yargı birliğinin sağlanabilmesi için eklektik metotla, günün şartlarını dikkate alan yeni bir Mecelle'nin hazırlanması gereklidir. Rızâeddin bu düşünce doğrultusunda uzun soluklu büyük bir mücadele vermesine rağmen yeni Mecelle çalışmaları akîm kalmıştır. Ancak Mecelle-i Ahkâm-ı Şer'iyye adıyla resmiyet kazanan yeni Mecelle çalışmaları akîm kalmış olsa da hem İslam hukuku hem de Rusya Müslümanları açısından önemli sonuçları olmuştur.

Rızâeddin b. Fahreddin'in yeni Mecelle mücadelesinin tarihî seyri genel itibariyle iki farklı dönemden oluşmaktadır. İlk dönem, Rızâeddin'in kadılığı ile başlayıp Bolşevik Devrimi'ne, ikincisi ise Bolşevik Devrimi'nden Rızâeddin'in vefatına kadar devam eden süreçtir. Bu iki dönem neredeyse birbirine zıt gelişmelerin yaşandığı zaman dilimleridir. İlk dönemde bir takım zorluklara rağmen belli bir istikrar sağlanmış ve sonuçta Mahkeme-i Şer'iyye özerkliğini kazanmıştır. İkinci dönemde ise, siyasi ve ekonomik sebeplerden dolayı istikrar git gide zayıflamış ve Mahkeme-i Şer'iyye sembolik bir kurum haline gelmiştir.

Rızâeddin'in Mahkeme-i Şer'iyye kadılığına seçilmesinden itibaren sistematik bir şekilde ortaya koyduğu yeni Mecelle mücadelesi, Mahkeme-i Şer'iyye'nin özerkliğini müteakiben ilk iş olarak yeni Mecelle girişiminde bulunulmasına ve bu hususta büyük bir ittifakın meydana gelmesini sağlamıştır. Mecelle-i Ahkâm-ı Şer'iyye, İslam hukuk tarihinde Osmanlı Devleti'nde hazırlanan Mecelle-i Ahkâm-ı Adliye ile başlayan yeni dönemin gelişmesine önemli katkı sağlayacak bir projedir. Çünkü bu projede muhteva çok daha geniş tutulmuş, usûl olarak da eklektik bir metot tercih edilmiştir. Ancak Ekim 1917 Bolşevik İhtilali ile bütün çalışmalar sekteye uğramıştır. Yeni Mecelle projesi de Rızâeddin b. Fahreddin'in Mahkeme-i Şer'iyye'ye Müftü seçilmesine kadar üzerinde herhangi bir çalışma yapılmadan öylece kalmıştır.

Rıâeddin b. Fahreddin'in müftü seçilmesi yeni Mecelle projesini yeniden gündeme getirmiştir. Temmuz 1924'de içerisinde bulunulan şartların zorluğu nedeniyle Mecelle-i Ahkâm-1 Şer'iyye projesine yeni bir usûl ile devam edilmesine karar verilmiştir. Buna göre; Mecelle başlangıçta planlandığı gibi bir komisyon tarafından değil, konunun uzmanı kabul edilen kişiler tarafından bölümler halinde yazılmasına ve eklektik bir metotla değil, mecbur kalınmadıkça sadece Hanefî mezhebi içtihatlarına göre tedvîn edilmesi uygun görülmüştür. Ancak bu çalışmalardan, Abdurrahman Ömerî tarafından hazırlanan bölümünün dışında herhangi bir bilgiye rastlanılmamıştır.

Rızâeddin'in yeni Mecelle mücadelesi altyapı mahiyetinde birçok çalışmanın yanı sıra, İslam hukuku açısından somut olarak iki önemli eserin meydana gelmesini 
162 Rızâeddin b. Fahreddin'in Yeni Mecelle Mücadelesi

RTEÜIFD

sağlamıştır. Bunlardan birincisi onun teşvik ve riyasetiyle Musa Carullah tarafından 1910 yılında hazırlanan yeni Mecelle'nin külli kâideleri mesabesindeki Kavâid-i Fıkhiyye'dir. Bu eser, Mecelle-i Ahkâm-ı Adliye'den aktarılan 99 külli kâideye, genel itibariyle Hanefî mezhebi içtihatlarından derlenen 102 kâide daha ilave edilerek hazırlanmıştır. İkinci önemli çalışma da Rızâeddin b. Fahreddin'in Mahkeme-i Şer'iyye'ye Müftü seçilmesi sonrasında yapılmıştır. Bu çalışma, Abdurrahman Ömerî tarafından 1926 yılında "Mecelle-i Ahkâm-ı Şer'iyye'nin Ailege Aid Kısmı" adıyla 551 madde olarak hazırlanan yeni Mecelle'nin aile hukukuna dair bölümüdür.

Rızâeddin b. Fahreddin'in yeni Mecelle'nin hazırlanması için verdiği büyük mücadelesi, bulunduğu coğrafyadan kaynaklandığını düşündüğümüz nedenlerden dolayı yeterince ilgi görmemiştir. 


\section{KAYNAKÇA}

Abdürreşit İbrahim. Rusya İmparatorluğu'nda Müslümanlar Çoban Yıldızı. haz. Seyfettin Erşahin. Ankara: SFN Televizyon Tanıtım Tasarım Yayıncılık, 2015.

Atar, Fahreddin. "Mahkeme". Türkiye Diyanet Vakfı İslam Ansiklopedisi, 27/338-341. Ankara: TDV Yayınları, 2003.

Aydın, Mehmet Âkif. "Hukuk-1 Âile Kararnamesi”, Türkiye Diyanet Vakfı Ansiklopedisi, 18/314-318. İstanbul: TDV Yayınları, 1998.

Baltanova, Goulnar. "Rızâeddin Fahreddin". Türkiye Diyanet Vakfı İslam Ansiklopedisi, 35/70-71. Ankara: TDV Yayınları, 2008.

Carullah (Bigiyef), Musa. Mülâhaza. Petragrad: Maksudof Matbaası, 1914.

Carullah, Musa. Islâhât Esasları. Petersburg: Tipografiya M.A. Maksutova, 1915.

Carullah, Musa. Uzun Günlerde Rûze. Kazan: Ümid Matbaası, 1911.

Daklad, Rusya Müslümanlarının İkinci Umumi Mahkeme-i Şer'iye Tarafından Daklad. Ufa: Şark Matbaası, 1917.

Devlet, Nadir, 1917 Ekim İhtilali ve Türk-Tatar Millet Meclisi. İstanbul: Ötüken Neşriyat, 1998.

Erdem, Sami. "Türkçede Mecelle Literatürü". Türkiye Araştırmaları Literatür Dergisi. 5 (2005), 673-722.

Kanlıdere, Ahmet. Reform Within Islam. İstanbul: Eren Yayıncılık, 1997.

Küçük Hamdi (Elmalılı Hamdi Yazır). “Makâle-i Mühimme”, Beyânü'l-Hak. 1/18, 399404.

Maraş, İbrahim. "Kazan Bölgesinde Yeni Mecelle Çalışmaları". Uluslararası Mecelle Sempozyumu. ed. Mustafa Artuç vd. Ankara: Türkiye Adalet Akademisi Yayınları, 2017, 280-292.

Mardin, Ebu'l-ulâ. Medeni Hukuk Cephesinden Ahmet Cevdet Paşa. Ankara: TDV Yayınları, 2009.

Mercânî, Şehâbeddîn b. Bahâiddîn el-Kazanî. Nâzûretü'l-Hakk fî Farziyyeti'l-Işâi ve in lem Yeğibi'ş-Şafak. Kazan: Şah Ahmed b. Hüsameddin Matbaası, 1287h.

Onar, Sıddık Sami. “Osmanlı İmparatorluğunda İslam Hukukunun Bir Kısminın Codification'u Mecelle”. İstanbul Üniversitesi Hukuk Fakültesi Mecmuası, 20/1-4, 57-85. 


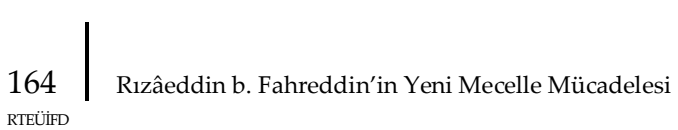

Rızaeddîn b. Fahreddîn. Menâsıb-ı Diniyye. Orenburg: Paravay Matbaası, ts.

Rızaeddîn b. Fahreddîn. Rusya Müslümanlarının İhtiyaçları ve Onlar Hakkında Intikâd. Orenburg: Kerimof Matbaası, 1906.

Rızaeddîn b. Fahreddîn. Din̂̂ ve İctimaî Meseleler. çev. Ömer Hakan Özalp. İstanbul: Özgü Yayınları, 2007.

Rızaeddîn b. Fahreddîn. Mütâlaa. Ufa: Fatih Kerimov Matbaası, 2. Basım, 1321/1903.

Rızaeddîn b. Fahreddîn. Tanzîmât. Kazan:Dombravski'nin Basımhanesi, 1898.

Rızaeddîn b. Fahreddîn. “Dinî ve İctimaî Meseleler”. Şûrâ, 7/24 (11 Safer 1333), 766.

Sa'fes (Yusuf Akçura). "Rusya'da Sakin Müslümanların Mahalle ve Müftülük Teşkilatı". Türk Yurdu 92/14 (10 Eylül 1331), 10-15.

Saray, Saray. "Altın Orda Hanlığı", Türkiye Diyanet Vakfi İslam Ansiklopedisi, 2/538-540. Ankara: TDV Yayınları, 1989.

Taymas, Abdullah Battal. Kazanlı Türk Meşhurlarından I; Rızâeddin Fahreddinoğlu. İstanbul: Birlik Basın ve Yayınevi, 1958.

Taymas, Abdullah Battal. Kazan Türkleri. Ankara: Türk Kültürü Araştırma Enstitüsü, 1966.

Troyskili Ahmed Tâceddîn. "Rusya Müslümanları ve Üç Mesele". Sırat-ı Müstakîm 2/33 (26 Mart 1325), 106-108.

Türkoğlu, İsmail. Rusya Türkleri Arasındaki Yenileşme Hareketinin Öncülerinden Rızâeddin Fahreddin. İstanbul: Ötüken Neşriyat, 2000.

Türkoğlu, İsmail. "Kazan Hanlığı". Türkiye Diyanet Vakfı İslam Ansiklopedisi, 25/136138. Ankara: TDV Yayınları, 2002.

Türkrus. Erişim 27 Mart 2021. https://www.turkrus.com/145365-rusyada-23-yillikmuftu-gorevi-devretti-ama-musluman-orgutleri-birlesemedi--xh.aspx.

Ünal, Fatih. "Geçmişten Günümüze As-Tarhan (Astrahan/Hacı Tarhan)”. Atatürk Üniversitesi Türkiyat Araştırmaları Enstitüsü Dergisi 38/250 (2008), 227-252.

Velidedeoğlu, Hıfzı Veldet. Kanunlaştırma Hareketleri ve Tanzimat. İstanbul: Maarif Matbaas1, 1940.

Yazıcı, Nesimi. İlk Türk-İslam Devletleri Tarihi. Ankara: TDV Yayınları, 2002. 